Pan American Petroleum Corp. Moose Creek Unit No. 1

Sec. 29, T $4 \mathrm{~N}, \mathrm{R} 3 \mathrm{~W}$ (C.R.M.)

\begin{tabular}{|c|c|c|}
\hline Depth & Age & Remarks \\
\hline $0-600$ & & Unfossiliferous \\
\hline $900-990$ & Upper Cretaceous & $\begin{array}{l}\text { Contains an entirely arenaceous fauna, } \\
\text { including Cribrostomoides cretacea. Age } \\
\text { Upper Cretaceous. }\end{array}$ \\
\hline $990-1080$ & Santonian & $\begin{array}{l}\text { Good arenaceous fauna, including Cribros- } \\
\text { tomoides cretacea, Cribrostomoides cali- } \\
\text { forniensis, Marssonella oxycona, Silico- } \\
\text { sigmoilina sp., rare occurrence of Globo- } \\
\text { truncana lapparenti, and single broken } \\
\text { specimen of Marginulina curvisepta. }\end{array}$ \\
\hline $1080-1470$ & Upper Cretaceous & $\begin{array}{l}\text { Contains good arenaceous fauna as above. } \\
\text { No age deternination closer than Upper } \\
\text { Cretaceous can be made for this interval. }\end{array}$ \\
\hline $1470-1980$ & Upper Cretaceous & Contains good arenaceous fauna as above. \\
\hline $1980-2190$ & & $\begin{array}{l}\text { Arenaceous fauna including Cribrostomoides } \\
\text { cretacea with a rare occurence of } \\
\text { Globotruncana lapparenti. }\end{array}$ \\
\hline $2190-2880$ & & $\begin{array}{l}\text { First occurrence of Ammobaculites } \\
\text { fragmentarius. }\end{array}$ \\
\hline $2220-2880$ & Santonian & $\begin{array}{l}\text { Ammobaculites fragmentarius, Cribrosto- } \\
\text { moides cretacea, Marssonella oxycona, } \\
\text { Silicosigmoilina sp., Cribrostomoides } \\
\text { californiensis, Glomospire sp., a few } \\
\text { radiolarians, and scattered occurrence } \\
\text { of long-ranging Calcareous foraminifera. } \\
\text { Age Santonian. }\end{array}$ \\
\hline $2880-3400$ & Upper Cretaceous & Fauna as above, including radiolarians. \\
\hline $3400-3670$ & Upper Cretaceous & $\begin{array}{l}\text { Sparse arenaceous fauna of Cribrostomoides } \\
\text { cretacea, Glomospire sp., Radiolartans, } \\
\text { and rare occurrence of Globotruncana } \\
\text { lapparenti. }\end{array}$ \\
\hline
\end{tabular}


$3670-3790$

$3790-3880$

$3880-4120$

$4120-4450$

$4450-4810$

$4810-4900$

$4900-5110$

$5110-5630$

$5630-5700$

$5700-5750$

Cenomanian

$5750-6030$

$6030-6180$

Santonian
PALENONTOLOGY RECORD

Pan American Petroleum Corp. Moose Creek Unit No. 1

Sec. 29, T $4 \mathrm{~N}, \mathrm{R} 3 \mathrm{~W}$ (C.R.M.)

No fossils were found except Radiolarians.

No fossils were found.

Washed residues from this interval are very sandy, a few arenaceious foraminifera and Inoceramus prisms, Radiolarians, and very rare primitive arenaceous foraminifera are present.

Sandy as above with some soft coal.

Samples very sandy. On1y fossils present are Inoceramus prisms and Radiolarians.

First occurrence of red shale. Radiolarians are present. Also present is a sparse foraminiferal fauna different than any fauna seen to date in Copper River Basin. This fauna not identified in TAZLINA well.

Same fauna as above. Probab1y Upper Cretaceous, but not identical to any assemblage found in UNION NO. 1 TAZLINA.

Arenaceous fauna of Glomospire sp. and Cribrostomoides cretacea. A few longranging Calcareous foraminifera and Radiolarians plus Vaivulineria marianosi. (Reported from the Santonian and Cenomanian of California.)

Sparse fauna, mostly arenaceous foraminifera, with Raiolarians.

Arenaceous fauna as above plus a few Calcareous foraminifera, including Hedbergella planispira, a planktonic species which has been reported from the Cenomanian and Albian. No species were found in the samples known to be restricted to the Albian, conclusions are the interval is Cenomanian.

Mostly Radiolarians, with rare occurrence of foraminifera, none of which is a time marker.

Samples are very sandy and more or less unfossiliferous. 


\section{PALEONTOLOGY RECORD}

Pan American Petroleum Corp.

Moose Creek Unit No. 1

Sec. 29, T $4 \mathrm{~N}, \mathrm{R} 3 \mathrm{~W}$ (C.R.M.)

$6180-6250$

$2650-6610$

$6610-6760$

$6760-6780$

$6780-6950$

$6950-7010$

$7010-7070$

$7070-7150$

$7150-7400$

$7400-7520$

$7520-7610$

$7610-7650$

$7650-7860$

$5756-7820$
No fossils were found. Washed restdues diluted with mud additives.

No fossils were found. Washed residues diluted with mud additives.

Unfossiliferous .

Rare foraminifera not adequate for age determination.

Washed residues are very sandy. No fossils were found.

Unfossiliferous.

Rare foraminifera and tiny gastropods.

Unfossiliferous.

Unfossiliferous ,

Unfossiliferous.

Sparse fauna of Calcareous foraminifera. Probably Lower Cretaceous.

Unfossiliferous.

No fossils were found.

\section{SIDEWALL CORES}

No fossils were found.

Paleontologic identification made from unwashed ditch samples by Mr. J. B. Garrett, Pan American Petroleum Corporation, Research Center, Houston, Texas. 